\title{
Nitrification and denitrification in a eutrophic lake sediment bioturbated by oligochaetes
}

\author{
Jonas Martin Svensson $^{1, *}$, Alex Enrich-Prast ${ }^{2}$, Lars Leonardson ${ }^{1}$ \\ ${ }^{1}$ Department of Ecology/Limnology, Ecology Building, University of Lund, 22362 Lund, Sweden \\ ${ }^{2}$ Lab. Limnologia, Depto. de Ecologia, Universidade Federal do Rio de Janeiro, Cidade Universitária, Ilha do Fundão, \\ 21941-540 Rio de Janeiro, Brazil
}

\begin{abstract}
The influence on nitrification and denitrification of oligochaete Limnodrilus sp. and Tubifex tubifex bioturbation was determined in eutrophic lake sediment from the Basin of Lake Ringsjön in southern Sweden. Nitrification and denitrification activity was compared in sieved and in undisturbed sediment cores in laboratory mesocosms at 2 different concentrations of nitrate. Nitrification and total denitrification rates were positively correlated to oligochaete biomass between 0 and $4 \mathrm{~g}$ dry weight $\mathrm{m}^{-2}$ at both 33 and $268 \mu \mathrm{M}$ nitrate in the inflowing water. Denitrification $\left(d_{\mathrm{w}}\right)$ was relatively more stimulated by the oligochaetes at high concentrations of nitrate in the overlying water than at low nitrate concentrations. Though nitrification was enhanced by oligochaetes, this tended to reach a maximum between 3 and $5 \mathrm{~g}$ of oligochaete dry weight $\mathrm{m}^{-2}$. Comparison of the enhancement of denitrification by oligochaetes with other similar studies of denitrification in eutrophic sediment bioturbated by tube-dwelling chironomids indicates that at a similar biomass oligochaetes are less effective at mobilizing nitrate to deeper sediment layers. This is explained by the different ways oligochaetes and tube-dwelling chironomids bioturbate the sediment. Sieving and homogenising the sediment had no pronounced effect on rates of denitrification and nitrification compared to undisturbed sediment.
\end{abstract}

KEY WORDS: Denitrification $\cdot$ Nitrification $\cdot$ Nitrogen-cycling $\cdot$ Oligochaetes $\cdot$ Bioturbation $\cdot$ Lake Eutrophic $\cdot$ Sediment $\cdot$ Sieving

- Resale or republication not permitted without written consent of the publisher

\section{INTRODUCTION}

In the various and extensive efforts to understand the regulation of bacterial nitrification and denitrification in sediments, bioturbation by benthic tube-dwelling animals (e.g. polychaetes, amphipods and chironomids) has been shown to play an important role in estuaries and freshwater (e.g. Krantzberg 1985, Kristensen 1988, Kristensen et al. 1991, Pelegrí et al. 1994, Pelegrí \& Blackburn 1994, 1995a,b, 1996, Svensson \& Leonardson 1996, Svensson 1997, 1998, Svensson et al. 2000). By constructing burrows, animals not only increase the surface of the sediment-water interface (Kristensen 1984), they also intermittently pump bottom water

${ }^{*}$ E-mail: jonas.svensson@limnol.lu.se through the burrows. Through their water-pumping activity, the animals mobilise nitrate to deeper parts of the sediment, shortening the diffusive distance of nitrate to the anaerobic zones where denitrification takes place (Kristensen 1988, Kristensen et al. 1991, Pelegrí et al. 1994, Svensson \& Leonardson 1996). These effects are further enhanced, since burrows are sites of higher bacterial numbers and metabolic activity than the surrounding sediment underlying the sediment surface (Aller \& Yingst 1978, Henriksen et al. 1983, Kristensen 1985, Kristensen et al. 1991).

In addition to polychaetes and chironomids, oligochaetes are a widely distributed group of infaunal benthos. High abundance of oligochaetes is often associated with highly polluted (organic-rich) sediments since some species are physiologically adapted to toler- 
ate low oxygen tension. Oligochaetes construct complicated burrow networks, although these cannot be considered permanent, unlike burrows made by polychaetes and chironomids. Conveyor-belt species such as oligochaetes process sediment particles mainly from a layer below the sediment surface (McCall \& Tevesz 1982) and defecate on top of the sediment. This strategy keeps the worms' food supply continuously renewed and unpolluted by recently digested material (Alsterberg 1925, Brinkhurst et al. 1972). It has been shown that oligochaetes transport overlying water to deeper sediment layers (Wood 1975) but they do not, however, ventilate their constructions to the same extent as chironomids (Leuchs 1986). On the other hand, oligochaetes have a higher capacity to redistribute particles compared to chironomids (Alsterberg 1925, Fukuhara et al. 1987). Thus, the way the oligochaetes rework or bioturbate the sediment differs from that of chironomids, and their influence on the nitrogen transformation processes is therefore expected to be different. This study investigates the influence of oligochaete worms Limnodrilus sp. and Tubifex tubifex on nitrification and denitrification in a eutrophic lake sediment. To evaluate the validity of measuring bacterial $\mathrm{N}$-cycling processes in sieved sediment, we compared nitrification and denitrification rates in sieved and in undisturbed sediment under similar experimental conditions.

\section{METHODS}

Sediment and oligochaete preparation. Sediment was collected from the Western Basin of the eutrophic Lake Ringsjön in southern Sweden (55 $\left.52^{\prime} \mathrm{N}, 13^{\circ} 32^{\prime} \mathrm{E}\right)$ in October 1996. Sediment (0 to $20 \mathrm{~cm}$ ) was collected with a modified Ekman grab (Downing 1984) from $5 \mathrm{~m}$ water depth and passed through a $0.55 \mathrm{~mm}$ mesh sieve in order to remove invertebrates, larger detritus and algal aggregates. On the same occasion, intact sediment cores from the same area were sampled with a modified Kajak corer equipped with plastic cylinders (length $30 \mathrm{~cm}$, area $36.3 \mathrm{~cm}^{2}$ ). The sediment was of algal origin and highly organic (Table 1).

Sieved sediment was stored in darkness in an open jar $\left(66\right.$ l) without active aeration at $4^{\circ} \mathrm{C}$. The undis-

Table 1. Characteristics of sieved and undisturbed surface sediment $(0-3 \mathrm{~cm})$ from Lake Western Ringsjön ( $n=2-3$ )

\begin{tabular}{|lccccc|}
\hline Sediment & $\begin{array}{c}\text { Porosity } \\
(\%)\end{array}$ & $\begin{array}{c}\text { Organic content } \\
(\%)\end{array}$ & $\begin{array}{c}\text { Weight C } \\
(\%)\end{array}$ & $\begin{array}{c}\text { Weight } \mathrm{N} \\
(\%)\end{array}$ & $\begin{array}{c}\text { C/N ratio } \\
(\mathrm{mol})\end{array}$ \\
\hline Undisturbed & $94.9 \pm 0.2$ & $36.1 \pm 0.7$ & $17.8 \pm 0.5$ & $1.78 \pm 0.05$ & $11.6 \pm 0.1$ \\
Sieved & $94.7 \pm 0.1$ & $34.5 \pm 0.1$ & $16.7 \pm 0.2$ & $1.56 \pm 0.03$ & $12.5 \pm 0.4$ \\
& & & & & \\
\hline
\end{tabular}

turbed cores were stored in the plastic tubes under identical conditions prior to use. On the day following sediment sampling, oligochaetes were collected from the 'biobeds' of a wastewater treatment plant outside Lund, Sweden. The oligochaetes were stored separately at the same temperature as the sediment $\left(4^{\circ} \mathrm{C}\right)$, together with a few stones from the biobed, in small, continuously aerated buckets containing Lake Ringsjön water. The concentration of nitrate in Lake Ringsjön ranges between 1 and $140 \mu \mathrm{mol} \mathrm{N} \mathrm{l^{-1 }}$ over the year.

Experimental design and sampling. After the sediment had settled and stabilised for about $2 \mathrm{wk}, 16$ Plexiglas cylinders (length $30 \mathrm{~cm}$, area $36.3 \mathrm{~cm}^{2}$ ) were pushed down into the open jar sediment and temporarily closed with butyl stoppers. One by one, 8 to $10 \mathrm{~cm}$ long sediment cores were withdrawn and moved to buckets, after which the overlying water phase was replaced by nitrate- and ammonium-free artificial lake water prepared according to Lehman (1980). The water volume above the sediment varied between 650 and $730 \mathrm{ml}$. Each core was equipped with a rotating magnetic stirrer connected to the cylinder wall and located 8 to $10 \mathrm{~cm}$ above the sediment surface, so the sediment would not be disturbed. The open cylinders were then equipped with airtight Plexiglas lids and transferred to a continuous flow-through system with a central magnet, modified according to RisgaardPetersen et al. (1994). Tubing for in- and outflow water was connected to the lids. The outflow tubing was made of chloropren rubber with low gas conductivity. All incubations were performed in darkness at $10^{\circ} \mathrm{C}$. Aerated nitrogen-free artificial lake water was fed into the overlying water of the cores at a constant rate of $111 \pm 11 \mathrm{ml} \mathrm{h}^{-1}$ using a peristaltic pump. After $1 \mathrm{~d}$ in the flow-through system, bioturbation was initiated by introducing oligochaetes to the cores. Zero, 20, 60 and 140 individuals were gently added to the sieved sediment cores in replicates of 3 . These numbers correspond to densities of $0,5500,16500$ and 38500 oligochaetes $\mathrm{m}^{-2}$, which is within the range normally found in eutrophic lakes. The oligochaetes immediately burrowed into the sediment after being introduced to the cores. No specimens were added to the undisturbed sediment cores.

Oxygen and ammonium measurements were taken over $10 \mathrm{~d}$ of preincubation to ensure that the magnetic stirring was sufficient to prevent vertical oxygen gradients in the water column. During initial pre-incubation the concentration of ammonium in the reservoir water was $0.7 \pm 0.1 \mu \mathrm{M}$. After about $6 \mathrm{~d}$ of pre-incubation, the concentration was artificially increased to 
$8.1 \pm 0.6 \mu \mathrm{M}$ in the reservoir supporting all treatments. This was done to ensure that nitrification was not ammonium limited. Following the pre-incubation period, ${ }^{15} \mathrm{~N}$-labelled $\mathrm{KNO}_{3}$ was added to the water supply reservoir. The amendments were chosen in order to obtain final concentrations of 33 and $268 \mu \mathrm{M}$ nitrate, 92 and $99 \%$ enrichment of ${ }^{15} \mathrm{NO}_{3}$ respectively, in the inflowing water. Reservoir water of each nitrate concentration was supplied to the cores for $3 \mathrm{~d}$. Sampling was carried out every 7 to $11 \mathrm{~h}$ during the last $2 \mathrm{~d}$. Water samples for analysis of oxygen and nitrogen species concentrations were collected with a $20 \mathrm{ml}$ gas-tight glass syringe from the outflow water. From the gastight syringes, samples of $12 \mathrm{ml}$ were evenly transferred to $12 \mathrm{ml}$ exetainers (Labco, UK) and kept for about 1 mo at $4{ }^{\circ} \mathrm{C}$, until analysis of the ${ }^{15} \mathrm{~N}$-labelled nitrogen was performed on a mass-spectrometer. Sieving (through a $0.55 \mathrm{~mm}$ mesh) the sediment from each core terminated the experiment. Survival and total dry weight $\left(60^{\circ} \mathrm{C}\right)$ of the oligochaetes were determined.

Analyses. The top $3 \mathrm{~cm}$ of both the sieved and the undisturbed sediment from duplicate cores was analysed for water content and organic content by drying at $100^{\circ} \mathrm{C}$ and loss on ignition at $450^{\circ} \mathrm{C}$, respectively. Analysing the $\mathrm{C} / \mathrm{N}$ ratio with a $\mathrm{CHN}$ elemental analyser (Fisons Instrument model NA 1500) also compared the sieved and undisturbed sediments. Dissolved oxygen concentrations were derived from Winkler titrations using an automatic potentiometric titrator (Mettler TM DL21) with high precision (0.1 to $0.3 \%$ coefficient of variance; Granéli \& Granéli 1991). Ammonium was determined according to Chaney \& Marbach (1962), and nitrate and nitrite according to Wood et al. (1967) on a Technicon Auto Analyzer II. Denitrification was analysed according to the nitrogenisotope pairing technique (Nielsen 1992). Two $\mathrm{ml}$ of the $12 \mathrm{ml}$ sample was replaced with helium. After vigorous shaking, $50 \mu \mathrm{l}$ of the gas phase was injected into a gas chromatograph in line with an isotope-ratio mass spectrometer (Hewlett-Packard 4100 GCMS) for analysis of ${ }^{15} \mathrm{~N}$-labelled dinitrogen pairs $\left({ }^{14} \mathrm{~N}^{15} \mathrm{~N}\right.$ and ${ }^{15} \mathrm{~N}^{15} \mathrm{~N}$ ) formed by denitrification. The $\%{ }^{15} \mathrm{NO}_{3}$ enrichment in the water phase of each core was determined by GCMS analysis following biological reduction of nitrate to dinitrogen (Risgaard-Petersen et al. 1993).

Calculations. Fluxes of oxygen, ammonium and nitrate were calculated using the general flux equation, $F=\left(C_{\mathrm{e}}-C_{\mathrm{i}}\right) V / A$, where $C_{\mathrm{e}}$ and $C_{\mathrm{i}}$ are respectively the effluent and influent concentrations of the nutrients, $V$ is the flow rate and $A$ is the surface area of the sediment. The oxygen consumption to time relationship was assumed to be linear (Granéli 1979).

The rates of denitrification per square meter were estimated using the ${ }^{15} \mathrm{~N}$-isotope pairing technique (Nielsen 1992). The production of single-labelled $\left({ }^{14} \mathrm{~N}^{15} \mathrm{~N}\right)$, and of double-labelled $\left({ }^{15} \mathrm{~N}^{15} \mathrm{~N}\right)$, dinitrogen pairs represents the respective net fluxes. These are used to calculate $d 15$ and $d 14$, which are the rates of denitrification of ${ }^{15} \mathrm{NO}_{3}$ and ${ }^{14} \mathrm{NO}_{3}$, respectively (Nielsen 1992).

$$
\begin{gathered}
d 15=\left({ }^{14} \mathrm{~N}^{15} \mathrm{~N}\right)+2\left({ }^{15} \mathrm{~N}^{15} \mathrm{~N}\right) \\
d 14=\left[d 15\left({ }^{14} \mathrm{~N}^{15} \mathrm{~N}\right)\right] / 2\left({ }^{15} \mathrm{~N}^{15} \mathrm{~N}\right)
\end{gathered}
$$

The rate of total denitrification caused by nitrate (of both ${ }^{14} \mathrm{NO}_{3}$ and ${ }^{15} \mathrm{NO}_{3}$ ) diffusing from the overlying water $\left(d_{\mathrm{w}}\right)$ was calculated from $d 15$ and $e$, where e represents the ${ }^{15} \mathrm{~N}$-labelled fraction of the $\mathrm{NO}_{3}$ of the effluent water (Rysgaard et al. 1993):

$$
d_{\mathrm{w}}=d 15 / e
$$

The rate of denitrification based on nitrification (coupled nitrification-denitrification) was calculated as the following difference:

$$
d_{\mathrm{n}}=(d 15+d 14)-d_{\mathrm{w}}
$$

The sum of $d_{\mathrm{w}}$ and $d_{\mathrm{n}}$ represents the total denitrification $\left(d_{\text {tot }}\right)$ as measured in each core.

The efflux of unlabelled $\mathrm{NO}_{3}$ originating from nitrification was estimated from the isotope dilution of the labelled nitrate, and total nitrification per square meter was further calculated by adding the gross unlabelled nitrate efflux $(R)$ and the coupled nitrification-denitrification $\left(d_{\mathrm{n}}\right)$ as described by Rysgaard et al. (1993):

$$
R=\left\{\left[C_{\mathrm{i}} \times(e-i)\right] /(0.366-e)\right\} \times V / A
$$

where $C_{\mathrm{i}}$ represents the inflow concentration of $\mathrm{NO}_{3}$, $e$ and $i$ are the ${ }^{15} \mathrm{~N}$-labelled fractions of $\mathrm{NO}_{3}$ in the effluent and influent water, respectively, and 0.366 the ${ }^{15} \mathrm{~N}$ content of the nitrified ammonium.

Statistics. The effects of oligochaete biomass (independent variable) were tested on the dependent variables using simple linear regression. The residuals were plotted and tested for normality using the Kolmogorov-Smirnov test (Lilliefors test; Zar 1984). Where assumptions for normality were met, the effect of oligochaete biomass was further tested at the 2 nitrate concentrations on the dependent variables in an analysis of covariance (ANCOVA), with oligochaete biomass as covariate. Two-way analysis of variance (ANOVA) was employed to test for differences between dependent variables in undisturbed and sieved sediment.

\section{RESULTS}

\section{Sediment and oligochaetes}

The change in sediment characteristics due to sieving was marginal (Table 1). The average sediment porosity (water content) of the top $3 \mathrm{~cm}$ was $95 \%$ in 
both the sieved and the undisturbed sediment. The organic content (loss on ignition) was lowered by sieving, i.e. $36.1 \%$ (by dry weight, DW) in the undisturbed sediment relative to $34.5 \%$ in the sieved sediment. Sieving also resulted in a decrease in total $\mathrm{N}$ of $\mathrm{C}$ with 12.6 and $6.2 \%$, respectively, which increased the $\mathrm{C} / \mathrm{N}$ molar ratio by $7.8 \%$, i.e. from 11.6 in the undisturbed sediment cores to 12.5 in the sieved ones (Table 1).

Survival of oligochaetes was generally close to, or at, $100 \%$ at the end of the experiment, except in 1 core where $95 \%$ of the added oligochaetes were found to be dead. The results from this core were excluded from further data evaluation. The oligochaete densities were recalculated to biomass after weighing and the results expressed as g DW $\mathrm{m}^{-2}$. DW of added oligochaetes was $111 \pm 17 \mu \mathrm{g}$ ind $^{-1}$ (mean $\pm \mathrm{SD}$ ). Hence, the average densities of introduced oligochaetes correspond to 0 , $0.6,1.9$ and $4.3 \mathrm{~g} \mathrm{DW} \mathrm{m}^{-2}$ in the experiment with sieved sediment. The biomass of oligochaetes in the undisturbed sediment cores was $142 \pm 55 \mu \mathrm{g}$ DW ind. ${ }^{-1}$. The average biomass in the undisturbed sediment cores was calculated as $0.43 \mathrm{~g} \mathrm{DW} \mathrm{m}^{-2}$.

\section{Ammonium flux and oxygen consumption}

Ammonium flux was found to be negative, i.e. the sediment took up ammonium from the overlying water, and steady state occurred about $7 \mathrm{~d}$ after the incubations were initiated (Fig. 1). Outflow concentration of

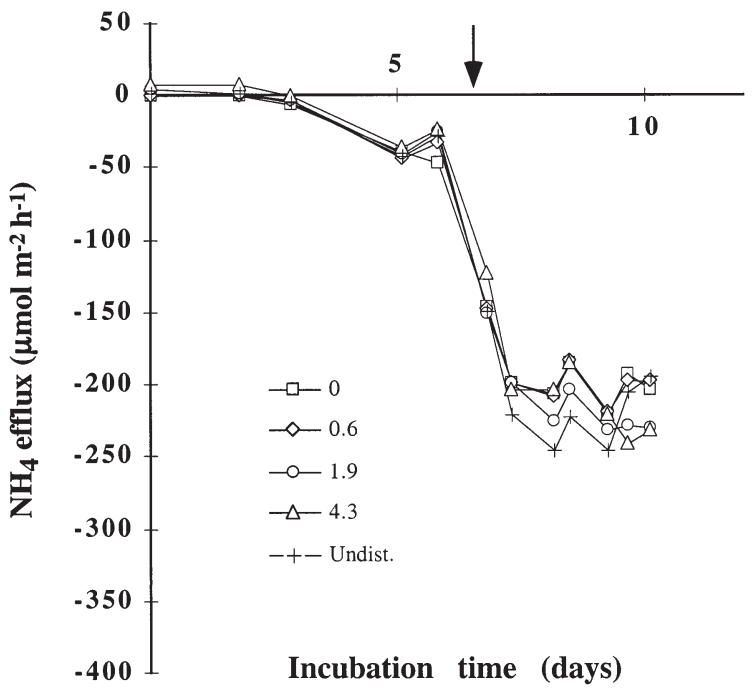

Fig. 1. Rates of ammonium flux in eutrophic sediment from the Western Basin of the eutrophic Lake Ringsjön, southern Sweden, in relation to incubation time for sieved sediment with $0,0.6,1.9,4.3 \mathrm{~g} \mathrm{DW}$ of oligochaetes $\mathrm{m}^{-2}$, and undisturbed (Undist.) sediment with $0.43 \mathrm{~g} \mathrm{DW} \mathrm{m}^{-2}$, respectively. Steadystate conditions occurred between 7 and $10 \mathrm{~h}$. Means of 3 to 4 cores are shown. Arrow indicates when ammonium was added to the water reservoir to a final concentration of $8.1 \mu \mathrm{M}$ ammonium ranged between 0.7 and $1.4 \mu \mathrm{M}$. No significant differences were found between the treatments either before or during the steady-state period. Just after the addition of ammonium to the reservoir water (see arrow in Fig. 1) the sediment responded by increasing the uptake of ammonium. Between 7 and $10 \mathrm{~d}$, when the main sampling for nitrogen species, nitrification and denitrification was conducted, the oxygen consumption remained stable, also indicating steadystate conditions. Average oxygen consumption was positively correlated $(F=8.5, \mathrm{p}<0.05$, ANOVA) to oligochaete biomass. Highest consumption, $1.67 \pm$ $0.67 \mathrm{mmol} \mathrm{O}_{2} \mathrm{~m}^{-2} \mathrm{~h}^{-1}$, was measured in the sieved sediment with an oligochaete biomass corresponding to $4.3 \mathrm{~g} \mathrm{DW} \mathrm{m}^{-2}$. In cores with $0,0.6$ and $1.9 \mathrm{~g} \mathrm{DW} \mathrm{m}^{-2}$ of oligochaetes, oxygen consumption was similar, $1.21 \pm$ $0.2,1.20 \pm 0.19$ and $1.19 \pm 0.14 \mathrm{mmol} \mathrm{O}_{2} \mathrm{~m}^{-2} \mathrm{~h}^{-1}$, respectively. The oxygen consumption in the undisturbed sediment cores containing $0.43 \mathrm{~g} \mathrm{DW}$ of oligochaetes was on average $1.30 \pm 0.40 \mathrm{mmol} \mathrm{O}_{2} \mathrm{~m}^{-2} \mathrm{~h}^{-1}$, i.e. somewhat higher $(6.3$ to $9.7 \%)$ than that recorded in sieved sediment cores with $0,0.6$ and $1.9 \mathrm{~g} \mathrm{DW} \mathrm{m}^{-2}$ of oligochaetes. However, no statistically significant difference was found between the undisturbed and the sieved cores with comparable biomasses of oligochaetes, i.e. 0 and $0.6 \mathrm{~g} \mathrm{DW} \mathrm{m}^{-2}$ ( $\mathrm{p}>0.05$, ANOVA).

\section{Sediment nitrate consumption}

The sediment net consumption of nitrate was higher at the greater nitrate load (Fig. 2). The nitrate consumption was further demonstrated to correlate to the

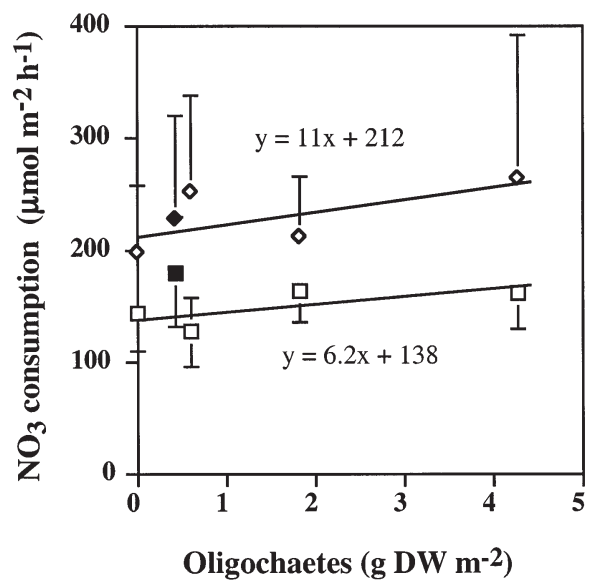

Fig. 2. Rates of net nitrate consumption in eutrophic sediment from Lake Ringsjön in relation to dry weight of oligochaetes at $33 \mu \mathrm{M}(\square)$ and $268 \mu \mathrm{M}(\diamond)$ nitrate in the inflowing water. Fitted lines are based on simple linear regression. Filled symbols represent rates of nitrate consumption measured in the undisturbed sediment cores at the 2 nitrate concentrations. Mean $\pm \mathrm{SD}, \mathrm{n}=8$ to 10 
biomass of oligochaetes in the sieved sediment at low nitrate concentration $(F=5.86, \mathrm{p}<0.05$, simple regression). Due to extensive variation, a similar correlation was not found at high nitrate concentration ( $p>0.05$ ). No difference was found between the slopes of regression of nitrate consumption at low and high concentrations of nitrate ( $p>0.05$, ANCOVA). The net nitrate consumption in the undisturbed cores at low nitrate concentration was significantly higher than that at corresponding biomasses in the sieved sediment cores, i.e. at 0 and $0.6 \mathrm{~g} \mathrm{DW} \mathrm{m}^{-2}$, and in the same order of magnitude as was registered at the higher biomasses. Due to the large variation at high nitrate concentrations, no difference was detected between sieved and undisturbed sediment.

\section{Nitrification}

Nitrification in the sieved sediment was correlated to the oligochaete biomass at both $33 \mu \mathrm{M}(F=39.7$, $\mathrm{p}<0.05$, second order polynomial regression) and $268 \mu \mathrm{M}(F=21.2, \mathrm{p}<0.05)$ nitrate in the inflowing water (Fig. 3). Maximum stimulation of nitrification by the oligochaetes was found at, or above, $5 \mathrm{~g} \mathrm{DW} \mathrm{m}^{-2}$ at low nitrate concentration, and at $3 \mathrm{~g} \mathrm{DW} \mathrm{m}^{-2}$ at the high nitrate level. In the control cores, i.e. at $0 \mathrm{~g}$ DW of oligochaetes $\mathrm{m}^{-2}$, nitrification rates were not significantly different between the 2 levels of nitrate $(\mathrm{p}>$ 0.05 , ANOVA). In the undisturbed sediment cores nitrification rates were lower than those observed in corresponding sieved sediment cores with additions of 0 and $0.6 \mathrm{~g} \mathrm{DW}$ of oligochaetes $\mathrm{m}^{-2}$. However, the rates

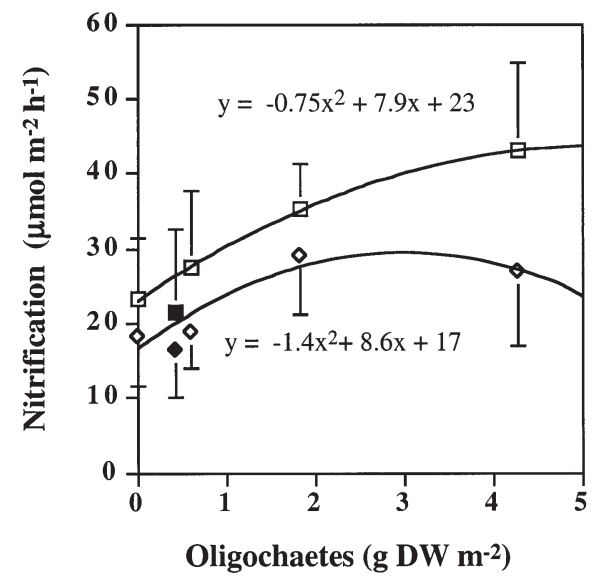

Fig. 3. Rates of nitrification in eutrophic sediment from Lake Ringsjön in relation to dry weight of oligochaetes at $33 \mu \mathrm{M}$ () and $268 \mu \mathrm{M}(\diamond)$ nitrate in the inflowing water. Fitted lines are based on secondary order polynomial regression. Filled symbols represent rates of nitrification measured in the undisturbed sediment cores at the 2 nitrate concentrations. Mean \pm $\mathrm{SD}, \mathrm{n}=8$ to 10 were not significantly different from those of the sieved sediment $(\mathrm{p}>0.05$, ANOVA).

\section{Denitrification}

Denitrification activity supported by nitrate diffusing from the overlying water $\left(d_{\mathrm{w}}\right)$ increased with increased biomass of oligochaetes at both low $(F=44.9, \mathrm{p}<0.05$, simple regression) and high $(F=53.8, \mathrm{p}<0.05)$ nitrate concentrations (Fig. 4a). The stimulation of $d_{\mathrm{w}}$ by the oligochaetes was greater at the higher nitrate concentration than at the lower concentration $(F=19.9, \mathrm{p}<$ 0.05, ANCOVA), 11.5 and $4.0 \mu \mathrm{mol} \mathrm{N} \mathrm{g} \mathrm{DW}{ }^{-1} \mathrm{~h}^{-1}$, respectively. In the undisturbed sediment $d_{\mathrm{w}}$ was similar to the rates observed in the sieved sediment cores at both low and high nitrate levels. Denitrification supported by nitrate from nitrification, i.e. coupled nitrification-denitrification $\left(d_{\mathrm{n}}\right)$, was significantly correlated to the oligochaete biomass $(F=4.4, \mathrm{p}<0.05)$ at the low

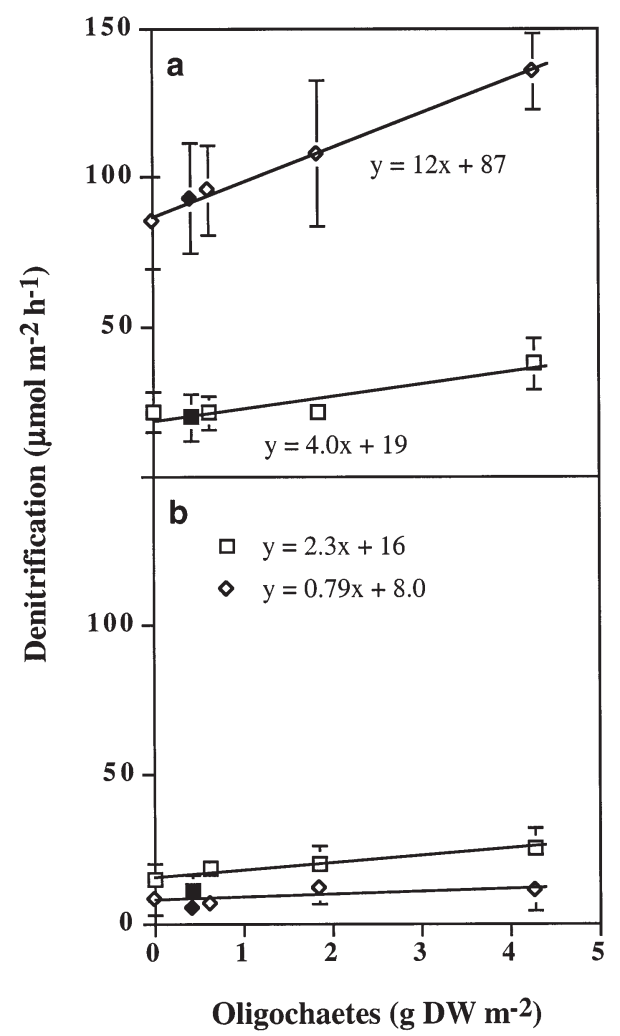

Fig. 4. (a) Rates of denitrification of nitrate from the water column $\left(d_{\mathrm{w}}\right)$ and $(\mathrm{b})$ of coupled nitrification-denitrification $\left(d_{\mathrm{n}}\right)$ in eutrophic sediment from Lake Ringsjön in relation to dry weight of oligochaetes at $33 \mu \mathrm{M}(\square)$ and $268 \mu \mathrm{M}(\diamond)$ nitrate in the inflowing water. Fitted lines are based on simple linear regression. Filled symbols represent rates of $d_{\mathrm{w}}$ and $d_{\mathrm{n}}$ measured in the undisturbed sediment cores at the 2 nitrate concentrations. Mean $\pm \mathrm{SD}, \mathrm{n}=8$ to 10 
nitrate concentration (Fig. 4b). This was not, however, observed at high nitrate concentration $(F=2.1, \mathrm{p}>$ 0.05), nor were the regression slopes of $d_{\mathrm{n}}$ at high and low nitrate significantly different $(F=2.0, \mathrm{p}>0.05$, ANCOVA). In the control cores, i.e. at $0 \mathrm{~g}$ DW of oligochaetes $\mathrm{m}^{-2}, d_{\mathrm{n}}$ rates were not significantly different between the 2 nitrate load levels ( $p>0.05$, ANOVA).

At $0 \mathrm{~g}$ DW of oligochaetes $\mathrm{m}^{-2}$ and low nitrate concentration, $d_{\mathrm{n}}$ made up $46 \%$ of total denitrification $\left(d_{\mathrm{tot}}\right)$, i.e. $d_{\mathrm{n}}$ plus $d_{\mathrm{w}}$. At high nitrate concentration and $0 \mathrm{~g} \mathrm{DW}$ $\mathrm{m}^{-2}, d_{\mathrm{n}}$ was $8.4 \%$ of $d_{\text {tot }}$. At $3 \mathrm{~g}$ DW of oligochaetes $\mathrm{m}^{-2}$ the proportions of $d_{\mathrm{n}} / d_{\text {tot }}$ were 42 and $7.9 \%$ at low and high concentrations of nitrate, respectively.

\section{DISCUSSION}

\section{Nitrification}

Nitrification was stimulated by the presence of oligochaetes at both low and high nitrate concentrations. The effect of oligochaete bioturbation on nitrification (and also denitrification) can be illustrated by considering the relative increase/decrease at different biomasses. At $3 \mathrm{~g} \mathrm{DW} \mathrm{m}^{-2}$ (ca 27000 ind. $\mathrm{m}^{-2}$ ), the stimulation of nitrification by the oligochaetes was $73 \%$ at low nitrate concentration, and $80 \%$ at high nitrate level above control samples. We use polynomial curve fits when considering a stream sediment study performed by Pelegrí \& Blackburn (1995b). In that study, at ca $11^{\circ} \mathrm{C}$, Pelegrí \& Blackburn (1995b) observed a $23 \%$ increase in nitrification when the oligochaete Tubifex tubifex density increased from 0 to 20000 ind. $\mathrm{m}^{-2}$. At higher oligochaete abundance nitrification decreased, and at 70000 ind. $\mathrm{m}^{-2}$ it was $30 \%$ lower than the maximum activity observed. The stimulation on nitrification in this present study is more pronounced but follows the same trend as the results of Pelegrí \& Blackburn (1995b), provided that the biomass of individual oligochaetes in the compared investigations is similar to that in our study. Pelegrí \& Blackburn (1995b) suggested that the decrease in nitrification was due to transport of faecal pellets to the sediment surface by the oligochaete conveyor-belt feeding activity, i.e. a continuous 1-way transport of faeces as recorded in several studies (e.g. Alsterberg 1925, Brinkhurst et al. 1972, Robbins 1986). This transport increases the load of organic material at the sediment surface and may initially, or at low biomass, stimulate nitrification by mobilising ammonium to the bacteria. However, a further increase of the load will enhance oxygen consumption and inhibit nitrification (Caffrey et al. 1993). Enhanced nitrification by oligochaetes was also reported by Chatarpaul et al. (1980): In stream sediment containing oligochaetes Tubifex tubifex and Limnodri- lus hoffmeisteri incubated at $15^{\circ} \mathrm{C}$, nitrification was enhanced $137 \%$ at densities of only 12000 and 16000 ind. $\mathrm{m}^{-2}$ compared to oligochaete-free sediment. The increased nitrification rates observed by Chatarpaul et al. (1980) were attributed to increased rate of sediment-water exchange of ammonium by the burrowing activities of the oligochaetes. Excretion of ammonia by oligochaetes was also suggested to contribute to the increased nitrification.

Oligochaete bioturbation can, hence, affect nitrification by a number of different mechanisms. However, in this study, it is difficult to separate the mechanisms involved. Oligochaetes may accelerate upward transport of ammonium (Chatarpaul et al. 1980), excrete amounts of ammonium (Gardner et al. 1983, Fukuhara \& Sakamoto 1987, Fukuhara \& Yasuda 1989) and increase sediment-water exchange of ammonium. In fact, the sediment in this study consumed almost all ammonium from the overlying water, strongly indicating nitrogen-limited sediment (Fig. 1). It may therefore be suspected that nitrification was partly supported with ammonium from the bottom water, induced by the feeding activity of the oligochaetes. However, the fate of the consumed ammonium is unknown and could be attributed to sediment uptake as well as to nitrification. Earlier findings reporting increased sediment redox potential (Hargrave 1972, 1975, Davis 1974, Matisoff et al. 1985) and porosity (Stockner \& Lund 1970, Fukuharaet al. 1987) support the potential for increased nitrification due to oligochaete bioturbation.

\section{Denitrification}

Both denitrification of water-column nitrate $\left(d_{\mathrm{w}}\right)$ and denitrification of nitrate from nitrification $\left(d_{n}\right)$ were enhanced by increased biomass of oligochaetes. At $3 \mathrm{~g}$ DW of oligochaetes $\mathrm{m}^{-2}$ (ca 27000 ind. $\mathrm{m}^{-2}$ ) and low nitrate concentration, $d_{\mathrm{w}}$ was stimulated to increase by $64 \%$, whereas at high nitrate concentration the increase was only $40 \%$ compared to controls without animals. Considering $d_{\mathrm{n}}$ at low and high nitrate concentrations, the stimulation at equal oligochaete density was 45 and $30 \%$, respectively. It should be noted that the absolute values of enhanced $d_{\mathrm{w}}$ are almost 3 times higher at the high nitrate concentration than at the low concentration (cf. regression coefficients in Fig. 4a).

Oligochaetes have previously been reported to enhance sediment denitrification in only a few studies. At 20000 ind. $\mathrm{m}^{-2}$, Pelegrí \& Blackburn (1995a) observed enhanced $d_{\mathrm{w}}$ by $83 \%$, while Chatarpaul et al. (1980) observed increased rates of $80 \%$ at animal densities between 12000 and 16000 ind. $\mathrm{m}^{-2}$. Despite the results of the present study indicating lower enhancement than the cited works, the patterns are still considered 
to agree rather well. The stimulation of denitrification in our study and in the studies by Pelegrí \& Blackburn (1995a) and Chatarpaul et al. (1980) is suggested to depend on oligochaete foraging behaviour. As they form numerous tunnels, the oligochaetes introduce currents of nitrate-rich water into deeper sediment layers and to sites of denitrifying bacteria. In this perspective it is interesting to compare the effects of oligochaetes on denitrification with the effects of tubedwelling chironomids as reported by several authors (Pelegrí \& Blackburn 1996, Svensson \& Leonardson 1996, Svensson 1997, 1998). Being conveyor-belt feeders, oligochaetes (tubificids) produce extensive mixing of the sediment. This mixing is more or less unidirectional, most simply described as a combination of diffusion and advection processes (Fischer et al. 1980, Matisoff 1982). In this context, advection is understood as the transport of dissolved components or particles with a flow of water and/or sediment caused by organisms (McCaffrey et al. 1980), in this case oligochaetes. This flow can be either random (biodiffusion) or directed (biopumping). The oligochaetes' capacity for redistributing or mixing sediment has been demonstrated in several papers (e.g. Robbins et al. 1979), whereas the significance of tube-dwelling organisms like chironomids has been questioned (Alsterberg 1925). Chironomids redistribute material mainly in the top sediment layer when constructing new burrows or during reconstruction (Lindeström 1979). During long periods of the year, they remain inactive within their burrows except for respiration movements, and their importance for the redistribution of sediment particles has therefore been considered small (e.g. Fukuhara 1987). On the other hand, chironomids constantly mediate the exchange of dissolved compounds over the sedimentwater interface by respiratory movements and regular water pumping activity (ventilation) in their constructions. This difference in bioturbation behaviour between oligochaetes and chironomids could explain why a certain biomass of chironomids enhances $d_{\mathrm{w}}$ to a larger extent relative to a similar biomass of oligochaetes. A comparison of this study with the studies on chironomid bioturbation by Svensson $(1997,1998)$ and Svensson \& Leonardson (1996) shows that the average increase in $d_{\mathrm{w}}$ caused by Chironomus plumosus bioturbation was slightly above 3.5 -fold (range 2.6 to 5.6 ) at a biomass of $5.1 \mathrm{~g} \mathrm{DW} \mathrm{m}^{-2}$. In the present study, the average relative rate of stimulation by the oligochaetes, recalculated as $5.1 \mathrm{~g} \mathrm{DW} \mathrm{m}^{-2}$, would be 1.8fold (range 1.7 to 1.9 ).

The nitrogen-isotope pairing technique is based on the assumption that ${ }^{28} \mathrm{~N}_{2},{ }^{29} \mathrm{~N}_{2}$ and ${ }^{30} \mathrm{~N}_{2}$ fluxes are binomially distributed (Hauck et al. 1958). Failure to fulfil this assumption leads to underestimation of denitrification (Nielsen 1992). A standard measurement to vali- date the method and to test that ${ }^{15} \mathrm{NO}_{3}$ does not interfere with denitrification of ${ }^{14} \mathrm{NO}_{3}$ is to add increasing amounts of ${ }^{15} \mathrm{NO}_{3}$ to the water column. Denitrification of ${ }^{14} \mathrm{NO}_{3}$ (generally not the same as $d_{\mathrm{n}}$ only when ${ }^{14} \mathrm{NO}_{3}$ is not present in the water) should then not increase with the increasing addition of ${ }^{15} \mathrm{NO}_{3}$. Here we have used 2 concentrations of nitrate at very high ${ }^{15} \mathrm{~N}$-labelling (92 and 99\%), which makes it possible to investigate if the bioturbating oligochaetes allow a uniform mixing of ${ }^{15} \mathrm{NO}_{3}$ and the naturally occurring ${ }^{14} \mathrm{NO}_{3}$ in aerobic zones before the ${ }^{15} \mathrm{NO}_{3}$ reaches anaerobic sites and is denitrified. $d_{\mathrm{w}}$ increased from $30.7 \mu \mathrm{mol} \mathrm{m} \mathrm{m}^{-2} \mathrm{~h}^{-1}$ at $33 \mu \mathrm{M}$ of nitrate to $121 \mu \mathrm{mol} \mathrm{m} \mathrm{m}^{-2}$ $\mathrm{h}^{-1}$ at $286 \mu \mathrm{M}$, while $d_{\mathrm{n}}$ did not increase with increasing nitrate concentration. This is confirmed by the nonsignificant difference between high and low nitrate concentrations at $0 \mathrm{~g}$ DW of oligochaetes $\mathrm{m}^{-2}$ and the non-significant difference between the slopes of regression of $d_{\mathrm{n}}$ at low and high nitrate concentrations. We therefore consider the major constraints of the method to be met.

\section{$d_{\mathrm{n}}$ relative to nitrification}

The oligochaetes in this study were not observed to increase the coupling between $d_{\mathrm{n}}$ and nitrification, i.e. the amount of nitrate produced from nitrification that is directly denitrified compared to total nitrification. This increased coupling was observed in a recent study where Chironomus plumosus enhanced the fraction of $d_{\mathrm{n}}$ to total nitrification (Svensson 1998), which was explained by the fact that chironomid ventilation increased the oxic zones for nitrification in deeper sediment layers, and also mediated the coupling or decreased the distance between produced nitrate and denitrification. However, $d_{\mathrm{n}}$ relative to nitrification was shown to be unaffected by the oligochaete's presence. At $0 \mathrm{~g}$ DW of oligochaetes $\mathrm{m}^{-2}$ the coupling was 64 and $41 \%$ at low and high nitrate concentrations, respectively, and at $3 \mathrm{~g} \mathrm{DW} \mathrm{m}^{-2}$ it was 59 and $40 \%$ at low and high nitrate concentrations. These results indicate that the observed increase in nitrification is taking place in the top sediment layers and not in deeper parts of the sediment. If nitrification is stimulated deep in the macrofaunal burrows, $d_{\mathrm{n}}$ would be expected to constitute a larger fraction of total nitrification in bioturbated sediment than in non-bioturbated sediment (Svensson 1998).

\section{Nitrate consumption}

The net consumption of water-column nitrate in the eutrophic sediment did not correspond to the esti- 
mated uncoupled denitrification $\left(d_{\mathrm{w}}\right)$. Denitrification only made up 20 to $50 \%$ of the sediment's nitrate uptake, of which the highest correlation was found at the higher nitrate concentration. The high nitrate consumption as well as the high sediment uptake of ammonium indicate that the sediment was N-limited, which might be a consequence of the storage and preincubation of the sediment depleting the pool of easily degradable organic material.

Dissimilative nitrate reduction to ammonium (DNRA) might also explain the discrepancy between uptake of nitrate and nitrate lost by denitrification. DNRA was, however, not measured in this study due to the opinion that this process is of limited significance in the types of sediment investigated, i.e. oxic conditions and sufficient loads of nitrate in the water phase. The results of our experiment agree with the results of Pelegrí \& Blackburn (1996), who reported that the denitrification in N-limited sediment only made up 20 to $30 \%$ of the total sediment uptake of nitrate. Yet another possible reason for the low denitrification relative to nitrate consumption may be that our study did not allow for measurement of the ${ }^{15} \mathrm{~N}_{2}$ diffusion to lower sediment strata. The ${ }^{15} \mathrm{~N}_{2}$ flux out of the sediment, as measured in this study, reflects the production in the sediment when this downwards diffusion from the denitrification zone is considered negligible.

\section{Effects of sieving on activity of nitrification and denitrification}

Sieving the sediment through a $0.55 \mathrm{~mm}$ sieve did not have a pronounced effect on sediment characteristics as expected. The porosity was almost unaffected by the treatment, and the organic content was lowered only slightly, from 36.1 to $34.5 \%$. The relative decrease was largest in total nitrogen, resulting in a slight increase in sediment $\mathrm{C} / \mathrm{N}$ ratio. This could be attributed to the loss of smaller animals and/or pieces of plants by sieving. Similar results, though it is difficult to calculate a $\mathrm{C} / \mathrm{N}$ ratio from their data, were reached by Day et al. (1995) when comparing unsieved and sieved Lake Eire sediment, which has a similar chemical composition as the sediment of Lake Ringsjön. After passing Lake Eire sediment through a $0.50 \mathrm{~mm}$ sieve, loss on ignition (organic content) dropped from about 33.5 to $29 \%$, total organic $\mathrm{C}$ from 13.2 to $11.2 \mathrm{mg} \mathrm{l}^{-1}$ and total nitrogen from 9620 to $8520 \mathrm{ppm}$.

In our study, it was further observed that sieving did not markedly affect denitrification (Fig. 4), but that nitrification (Fig. 3) was higher in the sieved sediment with corresponding oligochaete biomass. By examining phospholipids associated with different functional groups of microorganisms, Findlay et al. (1990) found that microbial growth rate was reduced as an initial effect of sieving. Microbial biomass was initially unaffected. A few hours later growth rates increased and biomass had decreased by $75 \%$. Biomass was again back to pre-disturbance values $8 \mathrm{~h}$ after the sieving disturbance. Their results also indicate that aerobic organisms (eucaryotic and procaryotic) were more severely affected by sieving than anaerobic organisms. This is in line with the results of the present study, i.e. the aerobic process of nitrification was more affected by sieving than the anaerobic process of denitrification. Nitrifiers are known to grow slowly (Kaplan 1983); thus, a slower recovery of this group of bacteria relative to denitrifiers might be expected after a disturbance event. There were also indications for a higher oxygen consumption in the undisturbed cores relative to cores with sieved sediment, i.e. cores with $0,0.6$ and 1.9 $\mathrm{g} \mathrm{DW}$ of oligochaetes $\mathrm{m}^{-2}$, which supports the idea that aerobic micro-organisms are more sensitive than anaerobic ones to disturbance events like sieving, as suggested by Day et al. (1995).

\section{Conclusion}

Nitrification and denitrification activities in an artificial system with eutrophic profundal sediment were stimulated by oligochaete bioturbation. However, the degree of stimulation of denitrification by oligochaetes is only about half that observed for tube-dwelling chironomids at corresponding biomass and similar environmental conditions (although not directly compared in this study; Svensson \& Leonardson 1996, Svensson 1997). This difference in degree of enhancement indicates that, at similar biomass, oligochaetes are less effective in mobilising nitrate to deeper sediment layers than tube-dwelling chironomids, which is suggested to be a result of different species-specific habitat exploitation. Still, the results indicate that oligochaetes at high abundance may be important links to overall nitrogen recirculation in eutrophic freshwater sediment.

Sieving the investigated eutrophic sediment affected the investigated nitrogen transformations to a limited extent only. Nitrification rates were in this way slightly reduced, whereas denitrification was unaffected in the sieved sediment compared to the undisturbed sediment.

Acknowledgements. We thank Dr Lars-Peter Nielsen and Prof. Wilhelm Granéli for valuable comments on an earlier version of the manuscript, and Dr Göran Bengtsson for use of the mass-spectrometer. Financial support was provided by The Royal Physiographical Society of Lund, The Swedish Environmental Protection Agency (SEPA) and The Swedish Foundation for International Cooperation and Higher Education (STINT). 


\section{LITERATURE CITED}

Aller RC, Yingst JT (1978) Biogeochemistry of tube-dwellings: a study of the sedimentary polychaete Amphitrite ornata (Leidy). J Mar Res 36:201-254

Alsterberg G (1925) Die Närhrungszirkulation einiger Binnenseetypen. Arch Hydrobiol 15:291-338

Brinkhurst RO, Chua KE, Kaushik NK (1972) Interspecific interactions and selective feeding of tubificid oligochaetes. Limnol Oceanogr 17:122-133

Caffrey JM, Sloth NP, Kaspar HF, Blackburn TH (1993) Effects of organic loading on nitrification and denitrification in a marine sediment microcosm. FEMS Microbiol Ecol 17:122-133

Chaney A, Marbach EP (1962) Modified reagents for determination of urea and ammonia. Clin Chem 8:130-132

Chatarpaul L, Robinson JB, Kaushik NK (1980) Effects of tubificid worms on denitrification and nitrification in stream sediment. Can J Fish Aquat Sci 37:656-663

Davis RB (1974) Tubificids alter profiles of redox potential and $\mathrm{pH}$ in profundal lake sediment. Limnol Oceanogr 19: 342-346

Day KE, Kirby RS, Reynoldson TB (1995) The effect of manipulations of freshwater sediments on responses of benthic invertebrates in whole-sediment toxicity tests. Environ Toxicol Chem 14:1333-1343

Downing JA (1984) Sampling the benthos of standing waters. In: Downing JA, Riegler FH (eds) A manual on methods for the assessement of secondary productivity in fresh waters. IBP Handbook 17, Blackwell Scientific Publications, Oxford, p 87-130

Findlay RH, Trexler MB, Guckert JB, White DC (1990) Laboratory study of disturbance in marine sediments: response of a microbial community. Mar Ecol Prog Ser 62:121-133

Fisher JB, Lick WJ, Robbins JA (1980) Vertical mixing of lake sediments by tubificid oligochaetes. J Geophys Res 85:3997-4006

Fukuhara H (1987) The effects of tubificids and chironomids on particle redistribution of lake sediment. Ecol Res 2: 255-264

Fukuhara H, Sakamoto M (1987) Enhancement of inorganic nitrogen and phosphate release from lake sediment by tubificid worms and chironimid larvae. Oikos 48:312-320

Fukuhara H, Yasuda K (1989) Ammonium excretion by some freshwater zoobenthos from eutrophic lake. Hydrobiologia 173:1-8

Fukuhara H, Othaka A, Isobe Y, Sakamoto M (1987) Seasonal changes in vertical distribution, biomass and faecal production of tubificids in the profundal region of a shallow Japanese lake. Holarctic Ecol 10:8-13

Gardner WS, Nalepa TF, Slavens DR, Laird GA (1983) Patterns and rates of nitro-gen release by benthic chironomidae and oligochaeta. Can J Fish Aquat Sci 40:259-266

Granéli W (1979) The influence of Chironomus plumosus larvae on the oxygen uptake of sediment. Arch Hydrobiol 87: 385-403

Granéli W, Granéli E (1991) Automatic potentiometric determination of dissolved oxygen. Mar Biol 108:341-348

Hargrave BT (1972) Oxidation-reduction potentials, oxygen concentration and oxygen uptake of profundal sediments in a eutrophic lake. Oikos 23:167-177

Hargrave BT (1975) Stability in structure and function of the mud-water interface. Verh Int Verein Limnol 19: 1073-1079

Hauck RD, Melsted SW, Yankwich PE (1958) Use of N-isotope distribution in nitrogen gas in the study of denitrification. Soil Sci 86:287-291
Henriksen K, Rasmussen MB, Jensen A (1983) Effect of bioturbation on microbial nitrogen transformation in the sediment and fluxes of ammonium and nitrate to the overlaying water. Ecol Bull 35:193-205

Kaplan WA (1983) Nitrification. In: Carpenter JE, Capone DG (eds) Nitrogen in the marine environment. Academic Press, New York, p 139-190

Kranzberg G (1985) The influence of bioturbation on physical and biological parameters in aquatic environments: a review. Environ Pollut Ser A 39:99-122

Kristensen E (1984) Effect of natural concentrations on nutrient exchange between a polychaete burrow in estuarine sediment and the overlying water. J Exp Mar Biol Ecol 75: 171-190

Kristensen E (1985) Oxygen and inorganic nitrogen exchange in a Nereis virens (Polychaeta) bioturbated sedimentwater system. J Coast Res 1:109-116

Kristensen E (1988) Benthic fauna and biochemical processes in marine sediments: microbial activities and fluxes. In: Blackburn TH, Sörensen J (eds) Nitrogen cycling in coastal marine environments. Wiley \& Sons, Chichester, p 175-190

Kristensen E, Jensen MH, Aller RC (1991) Direct measurment of dissolved inorganic nitrogen exchange and denitrification in individual polychaete (Nereis virens) burrows. J Mar Res 49:355-377

Lehman JT (1980) Release and cycling of nutrients between planktonic algae and herbivores. Limnol Oceanogr 15: 620-630

Leuchs H (1986) Die Schlängelaktivität von Chironomuslarven (Diptera) aus flachen und tiefen Gewässern und die resultierenden Wasserzirkulationen in Abgehängigkeit von Temperatur und Sauerstoffangebot. Arch Hydrobiol 108:281-299

Lindeström L (1979) Bioturbation i sediment i olika vattenmiljöer och dess betydelse för tungmetallers omsättning en litteraturstudie. IVL Rapport, Stockholm. Lindroth A (1942) Periodische Ventilationen bei der Larve von Chironomus plumosus. Zool Anz Bd 138:244-247

Matisoff G (1982) Mathematical models of bioturbation. In: McCall PL, Tevesz MJS (eds) Animal-sediment relation. Plenum Press, New York, p 289-331

Matisoff G, Fisher JB, Matis S (1985) Effects of benthic macroinvertebrates on the exchange of solutes between sediments and freshwater. Hydrobiologia 122:19-33

McCaffrey RJ, Myers AC, Davey E, Morrison G, Bender M, Luedtke N, Cullen D, Froelich P, Klinkenhammer G (1980) The relation between pore water chemistry and benthic fluxes of nutrients and manganese in Narraganasett Bay, Rhode Island. Limnol Oceanogr 25:31-44

McCall PL, Tevesz MJS (1982) Animal-sediment relations. Plenum Press, New York

Nielsen LP (1992) Denitrification in sediment from nitrogen isotope pairing. FEMS Microbiol Ecol 86:357-362

Pelegrí SP, Blackburn TH (1994) Bioturbation effects of the amphipod Corophium volutator on microbial nitrogen transformations in marine sediments. Mar Biol 121: 253-258

Pelegrí SP, Blackburn TH (1995a) Effect of bioturbation by Nereis sp., Mya arenaria and Cerastoderma sp. on nitrification and denitrification in estuarine sediments. Ophelia 42:289-299

Pelegrí SP, Blackburn TH (1995b) Effects of Tubifex tubifex (Oligochaeta: Tubificidae) on N-mineralization in freshwater sediments, measured with ${ }^{15} \mathrm{~N}$-isotopes. Aquat Microb Ecol 9:289-294

Pelegrí SP, Blackburn TH (1996) Nitrogen cycling in lake sediment bioturbated by Chironomus plumosus larvae, under 
different degrees of oxygenation. Hydrobiologia 325: 231-238

Pelegrí SP, Nielsen LP, Blackburn TH (1994) Dentrification in estuarine sediment stimulated by the irrigation activity of the amphipod Corophium volutator. Mar Ecol Prog Ser 105:285-290

Risgaard-Petersen N, Rysgaard S, Revsbech NP (1993) A sensitive assay for determination of the ${ }^{14} \mathrm{~N} /{ }^{15} \mathrm{~N}$ isotope distribution in nitrate. J Microbiol Meth 17:155-164

Risgaard-Petersen N, Rysgaard S, Revsbech NP (1994) Diurnal variation of denitrification and nitrification in sediments colonized by benthic microphytes. Limnol Oceanogr 39:573-579

Robbins JA (1986) A model for particle-selective transport of tracers in sediments with conveyor belt deposit feeders. J Geophys Res 91:8542-8558

Robbins JA, McCall PL, Fischer JB, Krezoski JR (1979) Effects of deposit feeders on migration of ${ }^{137} \mathrm{Cs}$ in lake sediments. Earth Planet Sci Lett 42:277-287

Rysgaard S, Risgaard-Petersen N, Nielsen LP, Revsbech NP (1993) Nitrification and denitrification in lake and estuarine sediments measured by the ${ }^{15} \mathrm{~N}$ dilution technique and isotope pairing. Appl Environ Microbiol 59: 2093-2098

Editorial responsibility: Gary King,

Walpole, Maine, USA
Stockner JG, Lund JWG (1970) Live algae in postglacial lake deposits. Limnol Oceanogr 15:41-58

Svensson JM (1997) Influence of Chironomus plumosus L. on ammonium flux and denitrification (measured by the acetylene blockage- and the isotope pairing-technique) in eutrophic lake sediment. Hydrobiologia 346:157-168

Svensson JM (1998) Emission of $\mathrm{N}_{2} \mathrm{O}$, nitrification and denitrification in a eutrophic lake sediment bioturbated by Chironomus plumosus. Aquat Microb Ecol 14:289-299

Svensson JM, Leonardson L (1996) Effects of bioturbation by tube-dwelling chironomid larvae on oxygen uptake and denitrification in eutrophic lake sediments. Freshw Biol 35:101-112

Svensson JM, Carrer GM, Bocci M (2000) Nitrogen cycling in sediments of the Lagoon of Venice, Italy. Mar Ecol Prog Ser 199:1-11

Wood ED, Armstrong FAJ, Richards FA (1967) Determination of nitrate in sea water by cadmium-cupper reduction to nitrite. J Mar Biol Assoc UK 47:23-31

Wood LW (1975) Role of oligochaetes in the circulation of water and solutes across the mud-water interface. Verh Int Verein Limnol 19:1530-1533

Zar JH (1984) Biostatistical analysis. Prentice-Hall, Englewood Cliffs, NJ

Submitted: June 14, 2000; Accepted: November 1, 2000

Proofs received from author(s): January 15, 2001 